\title{
Minat Belajar Peserta Didik dalam Pembelajaran PJOK Secara Daring
}

\author{
Kristiani Ekaristi Br Tarigan ${ }^{1 *}$, Made Agus Wijaya², Ni Putu Dwi Sucita Dartini ${ }^{3}$
}

1,2,3 Prodi Pendidikan Jasmani, Kesehatan dan Rekreasi, Universitas Pendidikan Ganesha, Singaraja, Indonesia

\section{ART I CLE I N F O \\ Article history: \\ Received May 09, 2021 \\ Revised May 16, 2021 \\ Accepted September 19, 2021 \\ Available online October 25, 2021}

Kata Kunci:

Minat belajar, PJOK,

pembelajaran daring

Keywords:

Learning Interest, PJOK, online learning

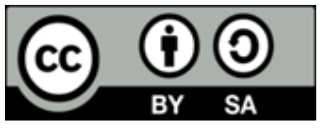

This is an open access article under the CC BY-SA license.

Copyright () 2021 by Author. Published by Universitas Pendidikan Ganesha.

\begin{abstract}
A B S T R A K
Terlaksananya pembelajaran PJOK secara daring berpengaruh terhadap minat belajar peserta didik dalam mengikuti kegiatan pembelajaran sehingga mempengaruhi hasil belajar peserta didik. Penelitian ini bertujuan untuk mengetahui minat belajar Peserta Didik pada Pembelajaran PJOK di Masa Pandemi Covid-19 SMP Negeri 5 Singaraja khususnya kelas VII dan VIII. Penelitian ini termasuk dalam jenis penelitian deskriptif kuantitatif dengan metode survei. Populasi dalam penelitian ini yaitu seluruh peserta didik kelas VII dan VIII SMP Negeri 5 Singaraja, dimana teknik sampling yang digunakan dalam penelitian ini adalah simple random sampling, diperoleh jumlah sampel sebanyak 233 orang peserta didik. Analisis data yang digunakan dalam penelitian ini adalah statistik deskriptif kuantitatif-kualitatif dengan kategori rentanan skala. Hasil penelitian menunjukkan terdapat $9(3,86 \%)$ peserta didik dalam kategori sangat tinggi, $133(57,08 \%)$ peserta didik dalam kategori tinggi, $86(36,91 \%)$ dalam kategori sedang, $4(1,72 \%)$ peserta didik dalam kategori rendah dan $1(0,43 \%)$ peserta didik dalam kategori sangat rendah. Berdasarkan analisis data dan pembahasan, simpulan penelitian ini adalah minat belajar peserta didik dalam pembelajaran PJOK secara daring di SMP Negeri 5 Singaraja termasuk pada kategori tinggi, dengan rata-rata skor mencapai 81,62. Disarankan kepada guru untuk meningkatkan minat belajar peserta didik guna memperlancar proses pembelajaran PJOK secara daring dengan memperhatikan fator internal dan eksternal yang mempengaruhi minat peserta didik.
\end{abstract}

\begin{abstract}
A BS T R A K
The implementation of online PJOK learning affects the interest of students in participating in learning activities so that it affects student learning outcomes. This study aims to determine the interest in learning of students in PJOK learning during the Covid-19 pandemic at SMP Negeri 5 Singaraja, especially grades VII and VIII. This research is included in the type of quantitative descriptive research with a survey method. The population in this study were all students of class VII and VIII of SMP Negeri 5 Singaraja, where the sampling technique used in this study was simple random sampling, obtained a total sample of 233 students. The data analysis used in this research is quantitativequalitative descriptive statistics with a scale vulnerability category. The results showed that there were 9 (3.86\%) students in the very high category, 133 (57.08\%) students in the high category, 86 (36.91\%) in the medium category, 4 (1.72\%) students students in the low category and $1(0.43 \%)$ students in the very low category. Based on data analysis and discussion, the conclusion of this study is that students' interest in learning PJOK online at SMP Negeri 5 Singaraja is included in the high category, with an average score of 81.62. It is recommended for teachers to increase students' interest in learning in order to facilitate the online PJOK learning process by paying attention to internal and external factors that affect student interest.
\end{abstract}

\section{PENDAHULUAN}

Melihat situasi pendidikan tengah pandemi Covid-19 kegiatan belajar mengajar dapat dilakukan dengan pembelajaran daring. Pembelajaran daring merupakan sebuah pembelajaran yang dilakukan dalam jarak jauh melalui media berupa internet dan alat penunjang lainnya seperti telpon seluler dan 
kompter (Handarini \& Wulandari, 2020; Primasari \& Zulela, 2021; Saifulloh \& Darwis, 2020). Pelaksanaan kebijakan Pendidikan dalam masa darurat penyebaran Coronavirus Disesase (Covid-19) terkait proses belajar menyatakan bahwa belajar dari rumah melalui pembelajaran daring/jarak jauh dilaksanakan untuk memberikan pembelajaran yang bermakna bagi peserta didik.

Berdasarkan observasi dengan guru mata pelajaran Pendidikan Jasmani Olahraga dan Kesehatan (PJOK) melalui wawancara di SMP Negeri 5 Singaraja yang dilakukan mengenai pembelajaran daring yang memanfaatkan teknologi multimedia, seperti whatsapp, youtobe, zoom dan classroom seperti yang dikatakan oleh (Rahmawati \& Yuliati, 2020) . Pembelajaran daring lebih menekankan pada ketelitian peserta didik dalam menerima dan mengolah informasi yang disajikan secara online terutama dalam pembelajaran PJOK (Magdalena, Hanifah, Agustin, \& Fitriani, 2021). Dimana PJOK merupakan salah satu pembelajaran wajib dan juga mendidik peserta didik ketika melaksanakan pembelajaran daring. Saat pembelaaran daring peserta didik dapat mempelajari aktivitas olahraga dapat membantunya untuk meningkatkan kebugaran jasmani para peserta didik (Dartini, Suwiwa, \& Spyanawati, 2017).

PJOK merupakan satu mata ajar yang diberikan di jenjang sekolah tertentu yang merupakan salah satu bagian dari pendidikan keseluruhan yang mengutamakan aktivitas jasmani dan pembinaan hidup sehat untuk bertumbuh dan perkembangan jasmani, mental, sosial dan emosional yang serasi, selaras dan seimbang (Wardika, 2019). PJOK adalah suatu proses pembelajaran melalui aktivitas gerak yang didesain untuk meningkatkan kebugaran jasmani, mengembangkan keterampilan gerak, pengetahuan dan prilaku hidup sehat dan aktif, sikap sportif, dan kecerdasan emosi. Pembelajaran PJOK tidak akan mencapai tujuan tanpa adanya rencana yang matang dalam proses pembelajarannya (Kemdikbud, 2017).

Proses pembelajaran PJOK pada masa pandemi ini dilaksanakan secara teratur dan berkesinambungan agar peserta didik memperoleh pengetahuan, kepribadian, keterampilan, kesehatan dan kebugaran jasmani. Seperti halnya terlihat di SMP Negeri 5 Singaraja dimana salah satu faktor yang mempengaruhi pembelajaran PJOK secara daring adalah minat belajar peserta didik (Fikri, Ananda, \& Faizah, 2021; Hutauruk \& Sidabutar, 2020; Raibowo \& Nopiyanto, 2020). Hal ini dikarenakan banyak kesulitan maupun kendala yang alami oleh peserta didik SMP Negeri 5 Singaraja sehingga mengakibatkan minat belajar peserta didik menjadi berkurang selama pembelajaran daring. Kurangnya minat belajar akan menimbukan sikap ketidaksenangan siswa terhadap belajar. sehingga banyak siswa yang tampak tidak memiliki keinginan belajar (Cahyaningtyas, 2020).

Suatu minat sangat berpengaruh pada proses belajar peserta didik dikarenakan minat merupakan suatu dasar terlaksananya kegiatan yang dilakukan oleh peserta didik selama proses pembelajaran secara daring. Minat sangat mendukung kelancaran proses belajar peserta didik, sehingga minat memberikan peranan yang cukup besar bagi keberhasilan belajar (Verawati, Tegeh, \& Antara, 2020). Apabila minat peserta didik menurun maka ketercapaian tujuan pembelajaran semakin rendah serta kualitas pembelajaran menurun sependapat dengan (Suprianto, 2020). Seperti di SMP Negeri 5 Singaraja dimana minat belajar peserta didik semakin menurun semenjak terlaksananya proses pembelajaran daring yang dipengaruhi oleh beberapa faktor. Adapun faktor yang menyebabkan minat peserta didik berkurang saat pembelajaran daring yaitu dari luar dan dalam seperti, kurang menyenangkan, kurangnya penjelasan tanpa praktik langsung, peserta didik merasa bosan, kesibukan orang tua dalam bekerja, quota, handphone, jaringan internet dan masih banyak lagi, sarana prasarana juga sangat penting dalam menunjang pembelajaran. Pentingnya peningkatan minat belajar peserta didik dalam pembelajaran daring menjadi fokus permasalahan yang harus segera diatasi agar kualitas belajar yang didapat lebih terarah (Darminto, 2017; Satyawan, 2015). Minat belajar peserta didik sangat perlu diperhatikan karena dengan adanya minat maka peserta didik akan melaksanakan kegiatan yang akan dan sedang dia laksanakan secara maksimal dengan kemampuan yang dimilikinya bahkan peserta didik akan berusaha dan memacu semangat belajarnya sehingga akan berdampak langsung pada hasil belajar dan kemampuannya. Setelah peserta didik memiliki minat untuk mulai belajar ditandai dengan proses rasa ingin tahu, bertanya, menalar, menguji coba dan menyimpulkan sendiri hal yang dipelajarinya (problem base learning), tentunya jika ingin menjaga kestabilan proses pembelajaran efektif maka guru harus bisa membantu peserta didik dalam menjaga minat belajarnya (Kompri, 2017).

Pendapat ini sejalan dengan hasil penelitian oleh (Yunitasari \& Hanifah, 2020) menyatakan, besarnya pengaruh minat belajar dalam pembelajaran PJOK terhadap hasil belajar peserta didik, serta penelitian oleh (Saleh \& Malinta, 2020) yang menunjukkan minat belajar peserta didik dalam pembelajaran pendidikan jasmani, olahraga dan kesehatan berada dalam kategori baik, atau dengan kata lain peserta didik menyetujui jika minat belajar mempengaruhi pembelajaran yang dilaluinya. Berdasarkan hal tersebut, minat peserta didik dalam mengikuti pembelajaran PJOK sangat membantu mempengaruhi proses belajar secara daring dan meningkatkan kualitas belajar seperti meningkatkan hasil belajar peserta didik. Dimana peserta didik memiliki kecenderungan belajar lebih baik ketika minat belajar meningkat dengan beberapa faktor yang mempengaruhinya. Sesuai dengan kasus yang terjadi 
perlu dilakukannya penelitian agar dapat mengetahui pengaruhi minat peserta didik dan pemecahan masalah agar dapat mengukur minat belajar peserta didik saat melalui proses pembelajaran. Dengan demikian dapat didefinisikan sebuah penelitian yang berjudul "Minat Belajar Peserta Didik dalam Pembelajaran PJOK Secara Daring di SMP Negeri 5 Singaraja". Berdasarkan hasil peneitian menyatkan bahwa analisis data pada faktor instrinsik mendapat rata-rata skor yaitu $79 \%$ dalam kategori tinggi. Sedangkan pada faktor ekstrinsik mendapat rata-rata skor yaitu $76 \%$ pada kategori tinggi. Dari kedua indikator pada variabel, minat peserta didik dalam mengikuti pembelajaran PJOK di masa pandemi covid19 memperoleh skor 78\% pada kategori tinggi. Maka dapat disimpulkan bahwa minat peserta didik dalam mengikuti pembelajaran PJOK dimasa pandemi covid-19 berada pada kategori tinggi. Namun ada beberapa kelemahan dalam penelitian ini yaitu pengisian kuesioner dilakukan secara daring melalui google form dan dikerjakan dirumah sehingga kejujuran dan fokus perhatian peserta didik dirasa kurang maksimal, kemungkinan untuk menjawab asal dari responden dalam mengisi kuesioner, adanya faktor ekstrinsik dan intrinsik mempengaruhi jawaban dari responden akibat belajar daring saat pandemi.

Perbedaan penelitian ini dengan beberapa penelitian tersebut yaitu penelitian ini dilakukan ketika terlaksananya pembelajaran daring sehingga dapat membantu menyelesaikan permasalahan yang dihadapi, fokus pembelajaran yang digunakan yaitu pembelajaran PJOK, proses penelitian yang dilakukan secara daring, subjek yang diteliti, dan tempat dilaksanakannya penelitian ini. Penelitian ini bertujuan untuk mengetahui minat belajar peserta didik dalam pembelajaran PJOK secara daring di SMP Negeri 5 Singaraja. Adapun kontribusi yang diberikan yaitu membantu menyelesaikan permasalahan dalam proses pembelajaran dan meningkatkan hasil belajar dengan memperbaiki minat belajar peserta didik.

\section{METODE}

Melihat situasi pendidikan tengah pandemi Covid-19 kegiatan belajar mengajar dapat dilakukan dengan pembelajaran daring. Pembelajaran daring merupakan sebuah pembelajaran yang dilakukan dalam jarak jauh melalui media berupa internet dan alat penunjang lainnya seperti telpon seluler dan kompter (Handarini \& Wulandari, 2020; Primasari \& Zulela, 2021; Saifulloh \& Darwis, 2020). Pelaksanaan kebijakan Pendidikan dalam masa darurat penyebaran Coronavirus Disesase (Covid-19) terkait proses belajar menyatakan bahwa belajar dari rumah melalui pembelajaran daring/jarak jauh dilaksanakan untuk memberikan pembelajaran yang bermakna bagi peserta didik.

Berdasarkan observasi dengan guru mata pelajaran Pendidikan Jasmani Olahraga dan Kesehatan (PJOK) melalui wawancara di SMP Negeri 5 Singaraja yang dilakukan mengenai pembelajaran daring yang memanfaatkan teknologi multimedia, seperti whatsapp, youtobe, zoom dan classroom seperti yang dikatakan oleh (Rahmawati \& Yuliati, 2020) . Pembelajaran daring lebih menekankan pada ketelitian peserta didik dalam menerima dan mengolah informasi yang disajikan secara online terutama dalam pembelajaran PJOK (Magdalena, Hanifah, Agustin, \& Fitriani, 2021). Dimana PJOK merupakan salah satu pembelajaran wajib dan juga mendidik peserta didik ketika melaksanakan pembelajaran daring. Saat pembelaaran daring peserta didik dapat mempelajari aktivitas olahraga dapat membantunya untuk meningkatkan kebugaran jasmani para peserta didik (Dartini, Suwiwa, \& Spyanawati, 2017).

PJOK merupakan satu mata ajar yang diberikan di jenjang sekolah tertentu yang merupakan salah satu bagian dari pendidikan keseluruhan yang mengutamakan aktivitas jasmani dan pembinaan hidup sehat untuk bertumbuh dan perkembangan jasmani, mental, sosial dan emosional yang serasi, selaras dan seimbang (Wardika, 2019). PJOK adalah suatu proses pembelajaran melalui aktivitas gerak yang didesain untuk meningkatkan kebugaran jasmani, mengembangkan keterampilan gerak, pengetahuan dan prilaku hidup sehat dan aktif, sikap sportif, dan kecerdasan emosi. Pembelajaran PJOK tidak akan mencapai tujuan tanpa adanya rencana yang matang dalam proses pembelajarannya (Kemdikbud, 2017).

Proses pembelajaran PJOK pada masa pandemi ini dilaksanakan secara teratur dan berkesinambungan agar peserta didik memperoleh pengetahuan, kepribadian, keterampilan, kesehatan dan kebugaran jasmani. Seperti halnya terlihat di SMP Negeri 5 Singaraja dimana salah satu faktor yang mempengaruhi pembelajaran PJOK secara daring adalah minat belajar peserta didik (Fikri, Ananda, \& Faizah, 2021; Hutauruk \& Sidabutar, 2020; Raibowo \& Nopiyanto, 2020). Hal ini dikarenakan banyak kesulitan maupun kendala yang alami oleh peserta didik SMP Negeri 5 Singaraja sehingga mengakibatkan minat belajar peserta didik menjadi berkurang selama pembelajaran daring. Kurangnya minat belajar akan menimbukan sikap ketidaksenangan siswa terhadap belajar. sehingga banyak siswa yang tampak tidak memiliki keinginan belajar (Cahyaningtyas, 2020).

Suatu minat sangat berpengaruh pada proses belajar peserta didik dikarenakan minat merupakan suatu dasar terlaksananya kegiatan yang dilakukan oleh peserta didik selama proses pembelajaran secara daring. Minat sangat mendukung kelancaran proses belajar peserta didik, sehingga minat memberikan peranan yang cukup besar bagi keberhasilan belajar (Verawati, Tegeh, \& Antara, 2020). Apabila minat 
peserta didik menurun maka ketercapaian tujuan pembelajaran semakin rendah serta kualitas pembelajaran menurun sependapat dengan (Suprianto, 2020). Seperti di SMP Negeri 5 Singaraja dimana minat belajar peserta didik semakin menurun semenjak terlaksananya proses pembelajaran daring yang dipengaruhi oleh beberapa faktor. Adapun faktor yang menyebabkan minat peserta didik berkurang saat pembelajaran daring yaitu dari luar dan dalam seperti, kurang menyenangkan, kurangnya penjelasan tanpa praktik langsung, peserta didik merasa bosan, kesibukan orang tua dalam bekerja, quota, handphone, jaringan internet dan masih banyak lagi, sarana prasarana juga sangat penting dalam menunjang pembelajaran. Pentingnya peningkatan minat belajar peserta didik dalam pembelajaran daring menjadi fokus permasalahan yang harus segera diatasi agar kualitas belajar yang didapat lebih terarah (Darminto, 2017; Satyawan, 2015). Minat belajar peserta didik sangat perlu diperhatikan karena dengan adanya minat maka peserta didik akan melaksanakan kegiatan yang akan dan sedang dia laksanakan secara maksimal dengan kemampuan yang dimilikinya bahkan peserta didik akan berusaha dan memacu semangat belajarnya sehingga akan berdampak langsung pada hasil belajar dan kemampuannya. Setelah peserta didik memiliki minat untuk mulai belajar ditandai dengan proses rasa ingin tahu, bertanya, menalar, menguji coba dan menyimpulkan sendiri hal yang dipelajarinya (problem base learning), tentunya jika ingin menjaga kestabilan proses pembelajaran efektif maka guru harus bisa membantu peserta didik dalam menjaga minat belajarnya (Kompri, 2017).

Pendapat ini sejalan dengan hasil penelitian oleh (Yunitasari \& Hanifah, 2020) menyatakan, besarnya pengaruh minat belajar dalam pembelajaran PJOK terhadap hasil belajar peserta didik, serta penelitian oleh (Saleh \& Malinta, 2020) yang menunjukkan minat belajar peserta didik dalam pembelajaran pendidikan jasmani, olahraga dan kesehatan berada dalam kategori baik, atau dengan kata lain peserta didik menyetujui jika minat belajar mempengaruhi pembelajaran yang dilaluinya. Berdasarkan hal tersebut, minat peserta didik dalam mengikuti pembelajaran PJOK sangat membantu mempengaruhi proses belajar secara daring dan meningkatkan kualitas belajar seperti meningkatkan hasil belajar peserta didik. Dimana peserta didik memiliki kecenderungan belajar lebih baik ketika minat belajar meningkat dengan beberapa faktor yang mempengaruhinya. Sesuai dengan kasus yang terjadi perlu dilakukannya penelitian agar dapat mengetahui pengaruhi minat peserta didik dan pemecahan masalah agar dapat mengukur minat belajar peserta didik saat melalui proses pembelajaran. Dengan demikian dapat didefinisikan sebuah penelitian yang berjudul "Minat Belajar Peserta Didik dalam Pembelajaran PJOK Secara Daring di SMP Negeri 5 Singaraja". Berdasarkan hasil peneitian menyatkan bahwa analisis data pada faktor instrinsik mendapat rata-rata skor yaitu $79 \%$ dalam kategori tinggi. Sedangkan pada faktor ekstrinsik mendapat rata-rata skor yaitu 76\% pada kategori tinggi. Dari kedua indikator pada variabel, minat peserta didik dalam mengikuti pembelajaran PJOK di masa pandemi covid19 memperoleh skor 78\% pada kategori tinggi. Maka dapat disimpulkan bahwa minat peserta didik dalam mengikuti pembelajaran PJOK dimasa pandemi covid-19 berada pada kategori tinggi. Namun ada beberapa kelemahan dalam penelitian ini yaitu pengisian kuesioner dilakukan secara daring melalui google form dan dikerjakan dirumah sehingga kejujuran dan fokus perhatian peserta didik dirasa kurang maksimal, kemungkinan untuk menjawab asal dari responden dalam mengisi kuesioner, adanya faktor ekstrinsik dan intrinsik mempengaruhi jawaban dari responden akibat belajar daring saat pandemi.

Perbedaan penelitian ini dengan beberapa penelitian tersebut yaitu penelitian ini dilakukan ketika terlaksananya pembelajaran daring sehingga dapat membantu menyelesaikan permasalahan yang dihadapi, fokus pembelajaran yang digunakan yaitu pembelajaran PJOK, proses penelitian yang dilakukan secara daring, subjek yang diteliti, dan tempat dilaksanakannya penelitian ini. Penelitian ini bertujuan untuk mengetahui minat belajar peserta didik dalam pembelajaran PJOK secara daring di SMP Negeri 5 Singaraja. Adapun kontribusi yang diberikan yaitu membantu menyelesaikan permasalahan dalam proses pembelajaran dan meningkatkan hasil belajar dengan memperbaiki minat belajar peserta didik.

Tabel 1. Kisi-kisi Instrumen Minat Belajar

\begin{tabular}{cccccc}
\hline \multirow{2}{*}{ No. } & \multirow{2}{*}{ Variabel } & \multirow{2}{*}{ Indikator } & Sub Indikator & Positif & Negatif \\
\hline \multirow{2}{*}{1} & \multirow{2}{*}{ Intrinsik } & Mengenal & $1,2,4$ & 3,5 \\
& \multirow{2}{*}{ Minat } & & Perasaan & 7,8 & $6,9,10$ \\
& Belajar & Kehendak & $11,12,14$ & 13,15 \\
2 & \multirow{2}{*}{ Ekstrinsik } & Sarana dan & $16,17,19$ & 18 \\
& & Prasarana & Aktivitas & $21,22,23,24$ & 20 \\
& & Guru & $26,29,30$ & 27,28 \\
\hline
\end{tabular}


Metode analisis data yang digunakan dalam penelitian ini adalah metode analisis deskriptif kuantitatif dan kualitatif (Sugiyono., 2016). Analisis deskriptif kuantitatif digunakan untuk mengolah data yang diperoleh dari kuesioner dalam bentuk skor dengan menggunakan skala Likert sebagai berikut.

Tabel 2. Skala Likert

\begin{tabular}{ccccl}
\hline No & Skor & Nilai Huruf & \multicolumn{1}{c}{ Respon } \\
\hline 1. & Skor 1 & A & Sangat tidak setuju \\
2. & Skor 2 & B & Tidak setuju \\
3. & Skor 3 & C & Setuju \\
4. & Skor 4 & D & Sangat setuju \\
\hline
\end{tabular}

Sumber: (Sukardi, 2008)

Untuk menghitung validitas isi kuesioner maka digunakan rumus uji validitas isi dari Gregory. Uji validitas isi bertujuan untuk menelaah ketetapan butir-butir instrumen ditinjau dari ketepatan isi instrumen dapat mengukur yang seharusnya diukur. Instrumen divalidasi oleh pakar ahli untuk mengetahui kesesuaian butir instrumen dengan materi atau indikator yang diukur (Widiartini, 2017).

Tabel 3. Penilaian Isi Kuesioner

\begin{tabular}{lccc}
\hline & & $\begin{array}{c}\text { Penilaian Pakar I } \\
\text { Releva Lemah } \\
\text { (Skor 1-2) }\end{array}$ & $\begin{array}{c}\text { Releva Kuat } \\
\text { (Skor 3-4) }\end{array}$ \\
\cline { 2 - 4 } Penilaian Pakar II & $\begin{array}{c}\text { Releva Lemah } \\
\text { (Skor 1-2) }\end{array}$ & & \\
& Releva Kuat & 7 & $1,2,3,4,5,6,8,9,10,11,12,13$, \\
& (Skor 3-4) & & $14,15,16,17,18,19,20,21,22$, \\
& & & $23,24,25,26,27,28,29,30$ \\
\hline
\end{tabular}
berikut ini.

Skor hasil penilaian pakar validitas isi, kemudian dikonversi dan kriteria validitas isi sesuai tabel

Tabel 4. Kriteria Validitas Isi

\begin{tabular}{cc}
\hline Rentangan Skor & Kriteria \\
\hline $0,80-1,00$ & validasi isi sangat tinggi \\
$0,60-0,79$ & validasi isi tinggi \\
$0,40-0,59$ & validasi isi sedang \\
$0,20-0,39$ & validasi rendah \\
$0,00-0,19$ & validasi sangat rendah \\
\hline
\end{tabular}

Penilaian 2 pakar yang dihitung dengan rumus uji Gregory didapatkan hasil 29 butir kuesioner dengan validitas contruct sebesar 0,97 dalam validitas isi sangat tinggi. Sehingga 29 butir kuesioner siap untuk dipergunakan dalam melakukan penelitian minat belajar peserta didik. Analisis deskriptif yang digunakan untuk mengetahui minat belajar peserta didik yang berdasarkan deskriptif frekuensi, sehingga diketahui frekuensi, persentase, dan nilai dengan interval kategori pada tabel 5.

Tabel 5. Skala Penilaian atau Kategori pada Skala Lima Teoretik

\begin{tabular}{ccc}
\hline No & Kriteria & Katagori \\
\hline 1. & $\mathrm{Mi}+1,5 \mathrm{SDi} \leq \mathrm{Mi}+3,0 \mathrm{SDi}$ & Sangat Tinggi \\
2. & $\mathrm{Mi}+0,5 \mathrm{SDi} \leq \mathrm{Mi}+1,5 \mathrm{SDi}$ & Tinggi \\
3. & $\mathrm{Mi}-0,5 \mathrm{SDi} \leq \mathrm{Mi}+0,5 \mathrm{SDi}$ & Sedang \\
4. & $\mathrm{Mi}-1,5 \mathrm{SDi} \leq \mathrm{Mi}-0,5 \mathrm{SDi}$ & Rendah \\
5. & $\mathrm{Mi}-3,0 \mathrm{SDi} \leq \mathrm{Mi}-1,5 \mathrm{SDi}$ & Sangat Rendah \\
\hline & & Sumber: Sugiyono, 2017
\end{tabular}

Rentang skala untuk menghitung respon minat belajar peserta didik dalam pembelajaran PJOK secara daring di SMP Negeri 5 Singaraja dapat dilihat pada Tabel 6. 
Tabel 6. Rentangan skala

\begin{tabular}{ccc}
\hline No & Rentang Skala & Katagori \\
\hline 1. & $95 \leq 116$ & Sangat Tinggi \\
2. & $80 \leq 94$ & Tinggi \\
3. & $65 \leq 79$ & Sedang \\
4. & $51 \leq 64$ & Rendah \\
5. & $29 \leq 50$ & Sangat Rendah \\
\hline
\end{tabular}

\section{HASIL DAN PEMBAHASAN}

Hasil

Data hasil penelitian didapatkan melalui jawaban responden dalam kuesioner yang diberikan. Kuesioner yang digunakan dalam penelitian ini telah di uji oleh 2 orang pakar yang berasal dari Universitas Pendidikan Ganesha. Kuesioner terdiri dari 29 butir pernyataan dengan 17 pernyataan positif dan 12 pernyataan negatif yang telah dilakukan berdasarkan peserta didik dan berdasarkan tiap-tiap pernyataan yang disajikan dalam tabel 6 sebagai berikut:

Tabel 7. Analisis Respon Peserta Didik

\begin{tabular}{llccc}
\hline No. & \multicolumn{1}{c}{ Rentang Nilai } & Frekuensi & Persentase & Kategori \\
\hline 1. & $95 \leq 116$ & 9 & $4 \%$ & Sangat Tinggi \\
2. & $80 \leq 94$ & 133 & $57 \%$ & Tinggi \\
3. & $65 \leq 79$ & 86 & $37 \%$ & Sedang \\
4. & $51 \leq 64$ & 4 & $2 \%$ & Rendah \\
5. & $29 \leq 50$ & 1 & $0 \%$ & Sangat Rendah \\
\hline
\end{tabular}

Sesuai dengan perolehan hasil yang didapatkan dengan menghitung skor respon peserta didik maka didapatkan hasil kuesioner sebesar 9 peserta didik dalam kategori tinggi 133 peserta didik dalam kategori tinggi, 86 peserta didik dalam kategori sedang, 4 peserta didik dalam kategori rendah dan 1 peserta didik dalam kategori sangat rendah. Sehingga rata-rata yang didapat dari 233 respon peserta didik dengan hasil skor 81,62 dalam kategori tinggi seperti terlihat pada grafik 1.

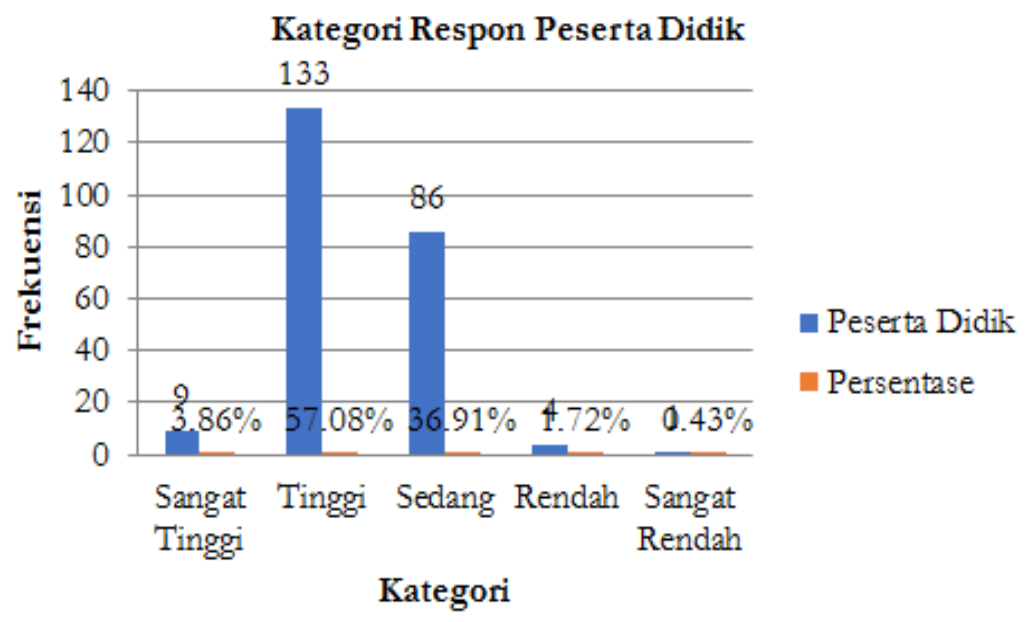

Gambar 1. Grafik Kategori Respon Peserta Didik

Setelah dilaksanakan observasi di SMP Negeri 5 Singaraja didapatkan beberapa masalah dalam proses pembelajaran terutama pada saat pembelajaran daring yang diterapkan akibat situasi pandemi. Adapun penurunan minat belajar peserta didik dilihat dari pengumpulan tugas yang diberikan oleh guru padapembelajaran PJOK. Dikarenakan ada beberapa permasalahan yang ditemukan maka perlu dilakukan penelitian guna memperbaiki hasil dan kualitas belajar.

Penelitian ini dilakukan untuk mengetahui seberapa besar minat belajar peserta didik dalam pembelajaran PJOK secara daring di SMP Negeri 5 Singaraja dengan sasaran peserta didik kelas VII dan VIII. Terdapat 2 indikator yang digunakan yaitu indikator intrinsik dan indikator ekstrinsik, dari 2 indikator tersebut didapatkan 6 sub indikator yang digunakan dalam penelitian ini yaitu mengenal, perasaan, kehendak, sarana dan prasarana, aktivitas dan guru. Selanjutnya dilakukan penyusunan 
kuesioner dan dilakukan pula serangkaian uji validasi instrument oleh 2 orang ahli yang membidangi penelitian ini untuk memaksimalkan respon peserta didik terhadap kuesioner yang diberikan. Menggunakan instrument berupa kuesioner dengan hasil 0,97 berada pada kategori isi sangat tinggi sehingga didapatkan 29 butir kuesioner yang layak dipergunakan untuk mengukur minat belajar peserta didik. Setelah kuesioner layak digunakan maka selanjutnya kuesioner disebarkan kepada peserta didik guna mendapatkan data yang bisa dioleh dan menentukan hasil dalam penelitian yang dilakukan.

\section{Pembahasan}

Minat adalah suatu dorongan yang menyebabkan terikatnya perhatian individu pada objek tertentu seperti pekerjaan, pelajaran, benda, dan orang (Jahya, 2015). Minat belajar merupakan salah satu faktor keberhasilam proses pembelajaran karena tumbuhnya minat belajar dalam diri siswa akan mendorong siswa untuk mengikuti pembelajaran dengan baik. Semakin tinggi minat belajar siswa akan meningkatkan hasil belajar siswa (Hadi, 2020). Guru adalah salah satu faktor yang memiliki peran dalam menumbuhkan minat belajar siswa. Sehingga selama pembelajaran daring, guru dituntut untuk menciptakan kegiatan belajar mengajar yang menarik dan bermakna agar dapat menumbuhkan minat siswa dalam belajar (Permata \& Bhakti, 2020; Pratiwi, 2020). Pembelajaran daring berpengaruh terhadap minat belajar siswa. Dikarenakan siswa menjadi mudah bosan ketika pembelajaran daring berlangsung. Pembelajaran kurang menarik tidak seperti pembelajaran di kelas. Oleh karena itu, guru harus menciptakan pembelajaran daring yang menarik dan meningkatkan minat belajar siswa (Yunitasari \& Hanifah, 2020). Faktor yang memepnagruhi minat belajar peserta didik adalah faktor ekstrinsik dan faktor intrinsik (Edy, Yasa, Adi, Luh, \& Spyanawati, 2020). Sangat selaras dengan sub indikator yang digunakan dalam penelitian ini yaitu mengenal perasaan, kehendak, sarana prasarana, aktivitas dan guru.

Indikator pertama, perasaan senang. dalam proses pembelajaran yang menjadi harapan guru adalah siswa tertarik dan berminat untuk mengikuti prose belajar dan mengajar dengan baik dan memperoleh hasil yang baik. Siswa akan menyukai kegaitan belajar apabila siswa sejak awal memiliki perasaan senang atau suka terhadap suatu mata pelajaran (Budiwibowo, 2016; Laksono, Ariyanti, \& Santoso, 2016). Selain itu adanya minat yang tinggi mampu mengarahkan siswa dalam mengikuti kegiatan pembelajaran dengan baik (Ningsih, Darsana, \& Abadi, 2018; Sari, Rakimahwati, \& Fitria, 2019). Indikator kedua, kehendak atau keinginan. Keinginan belajar siswa akna tumbuh apabila siswa memiliki minat serta rsa senang dan suka terhadap proses pembelajaran. Untuk menumbuhkan minat belajar peserta didik diperlukan kreatifitas guru dalam mengajar (Daheri, Juliana, Deriwanto, \& Amda, 2020; Saleh \& Malinta, 2020). Indikator ketiga sarana dan prasarana. Ketersediaan sarana dan prasarana untuk menunjang proses pembelajaran adalah faktor yang sangat penting dalam menumbuhkan minat belajar peserta didik. Karena sarana dan prasarana yang lengkap serta dalam kondisi yang baik akan memudahkan guru dalam menyampaikan materi sehingga siswa senang dan dalam belajar yang akan berpengaruh terhadap minat serta hasil belajar siswa. Pemilihan media yang tepat saat proses pembelajran secara daring adalah salah satu kunci kesuksesan guru dalam mengajar. Karena dengan media yang tepat materi yang disampaikan akan diterima dan mudah dipahami oleh peserta didik dengan baik (Imansyah, 2018; Sutapa, 2020). Pendapat ini diperkuat dengan hasil penelitian oleh (Nurrohim, 2020) yang menunjukkan bahwa peserta didik merasa puas terhadap pembelajaran daring. Kepuasan peserta didik di tunjukan dari faktor sarana dan prasarana yang memadai, bahan ajar yang digunakan sesuai, media pembelajaran yang digunakan sesuai, penguasaan materi guru, ketepatan penggunaan metode dan teknik, kepercayaan peserta dan kedisiplinan akan jadwal, kepuasan peserta didik sudah tercapai dalam kemampuan interaksi dan komunikasi, serta membimbing peserta didik untuk meningkatkan minat belajarnya. Tingkat pemahaman peserta didik pada pembelajaran daring dalam pembelajaran jasmani cukup baik karena adanya hambatan-hambatan berdasarkan faktor pendidikan luar kelas. Dimana dalam penelitian ini terdapat beberapa saran guna memperbaiki pembelajaran daring pada pembelajaran jasmani . (Fauzi, Achmad, \& R, 2020; Pangestu, Lanang, Parwata, \& Wijaya, 2021).

Penelitian ini menemukan bahwa minat belajar peserta didik yang tinggi sangat dipengaruhi oleh sumber informasi yang digunakan sebagai penujang, aktivitas yang dilakukan untuk menghilangkan rasa jenuh, keinginan untuk belajar dan melatih diri, sarana prasarana yang memadai seperti handphone, quota internet, jaringan internet, fokus belajar peserta didik, contoh atau arahan yang diberikan oleh guru, feedback guru terhadap tugas yang dikerjakan peserta didik, dan cara belajar yang diberikan guru sangat bervariasi untuk tetap menjaga minat belajar peserta didik selama belajar PJOK secara daring. Sehingga diharapkan guru mampu meningkatkan kreatifitas dengan menciptakan proses pembelajaran yang menyenangkan sehingga mampu menumbuhkan minat belajar siswa yang akan berdampak terhadap hasil belajarnya. 


\section{SIMPULAN DAN SARAN}

Simpulan dari hasil penelitian mengenai minat belajar peserta didik sangat berpengaruh tinggi untuk membantu memperbaiki proses mengajar dan hasil belajar peserta didik serta dapat dilakukan untuk semua tingkat pendidikan dalam sistem pembelajaran daring akibat pandemi dan telah didukung oleh penelitian-penelitian yang telah relevan. Implikasi penelitian ini yaitu minat belajar peserta didik mampu meningkatkan semangat belajar dan hasil yang dicapai, oleh karena itu perlu diperhatikan cara belajar yang diterapkan oleh peserta didik sehingga mampu meningkatkan minat belajarnya selama pembelajaran daring, dan faktor intrinsik (mengenal, perasaan, kehendak) dan faktor ekstrinsik (sarana prasarana, aktivitas, guru) dari minat belajar sangat berpengaruh besar bagi peserta didik yang dapat dijadikan point penting dalam mencapai tujuan pembelajaran.

\section{DAFTAR RUJUKAN}

Budiwibowo, S. (2016). Hubungan Minat Belajar Siswa Dengan Hasil Belajar IPS Di SMP Negeri 14 Kota Madiun. Retrieved From Http://EJournal.Unipma.Ac.Id/Index.Php/Gulawentah/Article/View/66.

Cahyaningtyas, T. N. (2020). Analisis Dampak Pandemi Virus Corona Terhadap Motivasi Belajar Siswa Kelas II SD Percobaan II Malang. Seminar Nasional PGSD UNIKAMA, 4, 1-7.

Daheri, M., Juliana, J., Deriwanto, D., \& Amda, A. D. (2020). Efektifitas Whatsapp Sebagai Media Belajar Daring. Jurnal Basicedu, 4(4), 775-783. Https://Doi.Org/10.31004/Basicedu.V4i4.445.

Darminto, A. O. (2017). Analisis Minat Belajar Penjas Terhadap Kemampuan Bermain Sepakbola Pada Siswa Putera SMA Negeri 1 Lamuru Kabupaten Bone. Jurnal Genta Mulia, 8(1), 1. Retrieved From Https://Ejournal.Stkipbbm.Ac.Id/Index.Php/Gm/Article/View/125.

Dartini, N. P. D., Suwiwa, I. G., \& Spyanawati, L. P. (2017). Tingkat Kebugaran Jasmani Siswa Kelas V Sekolah Dasar Gugus VI Kecamatan Sukasada. JURNAL PENJAKORA, 4(1), 27-37. Https://Doi.Org/10.23887/Penjakora.V4i1.11751.

Edy, K., Yasa, S., Adi, I. P. P., Luh, N., \& Spyanawati, P. (2020). Minat Peserta Didik Dalam Mengikuti Pembelajaran PJOK Di Masa Pandemi Covid-19. Indonesiam Journal Of Sport \& Tourism, 2(10), 32 37. Https://Doi.Org/Doi.Org/Http://Dx.Doi.Org/10.23887/Ijst.V2i2.34855.

Fauzi, R., Achmad, I. Z., \& R, A. K. Y. (2020). Tingkat Pemahaman Siswa Kelas X Dalam Pembelajaran Daring Pendidikan Jasmani Di Sman 2 Cikarang Pusat. Jurnal Pendidikan Olahraga, 3(2), 37-46. Https://Doi.Org/10.31602/Rjpo.V3i2.

Fikri, M., Ananda, M. Z., \& Faizah, N. (2021). Kendala Dalam Pembelajaran Jarak Jauh Di Masa Pandemi Covid-19: Sebuah Kajian Kritis. Jurnal Education And Development Institut Pendidikan Tapanuli Selatan, 9(1), 145-148. Https://Doi.Org/10.37081/Ed.V9i1.2290.

Hadi, L. (2020). Persepsi Mahasiswa Terhadap Pembelajaran Daring Di Masa Pandemik Covid-19 Student Perceptions Of Online Learning During Covid-19 Pandemic. Jurnal Zarah, 8(2), 56-61. Https://Doi.Org/10.31629/Zarah.V8i2.2464.

Handarini, O. I., \& Wulandari, S. S. (2020). Pembelajaran Daring Sebagai Upaya Study From Home (SFH) Selama Pandemi Covid 19, 8(1), 496-503. Https://Doi.Org/Https://Journal.Unesa.Ac.Id/Index. Php/Jpap/Article/View/ 8503/4094.

Hutauruk, A., \& Sidabutar, R. (2020). Kendala Pembelajaran Daring Selama Masa Pandemi Di Kalangan Mahasiswa Pendidikan Matematika: Kajian Kualiatatif Deskriptif. SEPREN: Journal Of Mathematics Education And Applied, 02(01), 45-51. Https://Doi.Org/10.36655/Sepren.V2i1.364.

Imansyah, F. (2018). Minat Belajar Siswa Pada Pelajaran Penjas Orkes Terhadap Hasil Belajar Pelajaran Penjas Orkes Siswa SMA Negeri Se-Kecamatan Pengandonan. In Prosiding Seminar Nasional. Retrieved From Palembang.Ac.Id/Index.Php/Prosidingpps/Article/View/2040/0.

Jahya, Y. (2015). Psikologi Perkembangan. Jakarta: Kencana.

Kemdikbud. (2017). Pendidikan Jasmani, Olahraga Dan Kesehatan Kelas XI. Jakarta: Kementrian Pendidikan Dan Kebudayaan.

Kompri, M. P. (2017). Belajar Faktor-Faktor Yang Mempengaruhinya. Jakarta: Media Akademi.

Laksono, Y. S., Ariyanti, G., \& Santoso, F. G. I. (2016). Hubungan Minat Belajar Siswa Terhadap Prestasi Belajar Matematika Siswa Dalam Pembelajaran Kooperatif Tipe Stad Menggunakan Komik. Jurnal Edukasi Matematika Dan Sains, 1(2), 60-64. Https://Doi.Org/10.25273/Jems.V1i2.143.

Magdalena, I., Hanifah, H., Agustin, J. T., \& Fitriani, M. A. (2021). Evaluasi Pembelajaran Bahasa Indonesia Secara Daring Materi Menulis Karangan Narasi Kelas V SDN Karangharja. Jurnal Pendidikan Dan 
Sains, 1(3), 164-176. Https://Doi.Org/10.36088/Bintang.V3i1.1289.

Mayang Ayu Sunami, \& Aslam. (2021). Pengaruh Penggunaan Media Pembelajaran Video Animasi Berbasis Zoom Meeting Terhadap Minat Dan Hasil Belajar IPA Siswa Sekolah Dasar. Jurnal Basicedu, 5(4), 1-9. Https://Doi.Org/10.31004/Basicedu.V5i4.1129.

Ningsih, N. L. P. R., Darsana, I. W., \& Abadi, I. B. G. S. (2018). Korelasi Antara Minat Belajar Dengan Hasil Belajar IPS. Mimbar PGSD Undiksha, 6(3), 202-209. Https://Doi.Org/10.23887/Jjpgsd.V6i3.21097.

Nurrohim, N. (2020). Analisis Kepuasan Siswa Kelas IX Sekolah Menengah Pertama Terhadap Pembelajaran Daring Mata Pelajaran PJOK Pada Masa Pandemi Covid-19 Kecamatan Purwanegara 2020. Journal of Physical Activity And Sports, 1(1), 133-146. Https://Doi.Org/10.53869/Jpas.V1i1.26.

Pangestu, B., Lanang, I. G., Parwata, A., \& Wijaya, M. A. (2021). Minat Dan Motivasi Berprestasi Siswa Dalam Mengikuti Kegiatan Ekstrakurikuler Bolavoli. Indonesian Journal of Sport \& Tourism, 3(November), 48-55. Https://Doi.Org/10.23887/Ijst.V3i2.31937.

Permata, A., \& Bhakti, Y. B. (2020). Keefektifan Virtual Class Dengan Google Classroom Dalam Pembelajaran Fisika Dimasa Pandemi Covid-19. JIPFRI Jurnal Inovasi Pendidikan Fisika Dan Riset Ilmiah), 4(1), 27-33. Https://Doi.Org/10.30599/Jipfri.V4i1.669.

Pratiwi, E. W. (2020). Dampak Covid-19 Terhadap Kegiatan Pembelajaran Online Di Perguruan Tinggi Kristen Di Indonesia. Perspektif Ilmu Pendidikan, 34(1), 1-8. Https://Doi.Org/10.21009/Pip.341.1.

Primasari, I. F. N. D., \& Zulela. (2021). Kendala Pembelajaran Jarak Jauh (PJJ) Secara Online Selama Masa Pandemik Covid-19 Di Sekolah Dasar. JIKAP PGSD: Jurnal Ilmiah Ilmu Kependidikan, 5(1), 64-73. Https://Doi.Org/10.26858/Jkp.V5i1.16820.

Rahmawati, I. Y., \& Yuliati, B. (2020). Kreativitas Guru Dalam Proses Pembelajaran Ditinjau Dari Penggunaan Metode Pembelajaran Jarak Jauh Di Tengah Wabah. AL-ASASIYYA: Journal Basic Of Education, 5(1), 27-39.

Raibowo, S., \& Nopiyanto, Y. E. (2020). Evaluasi Pembelajaran Pendidikan Jasmani Olahraga \& Kesehatan Pada SMP Negeri Se-Kabupaten Mukomuko Melalui Pendekatan Model Context , Input, Process \& Product ( CIPP ). Jurnal Pendidikan Kesehatan Rekreasi, 6(2), 146-165. Https://Doi.Org/10.5281/Zenodo.3881891.

Saifulloh, A. M., \& Darwis, M. (2020). Manajemen Pembelajaran Dalam Meningkatkan Efektivitas Proses Belajar Mengajar Di Masa Pandemi Covid-19. Bidayatuna: Jurnal Pendidikan Guru Mandrasah Ibtidaiyah, 3(2), 285. Https://Doi.Org/10.36835/Bidayatuna.V3i2.638.

Saleh, M. S., \& Malinta, S. S. (2020). Survei Minat Belajar Siswa Dalam Mengikuti Pembelajaran Pendidikan Jasmani Di SMPN 30 Makassar. Jurnal Kinestetik, 4(1), 55-62. Https://Doi.Org/10.33369/Jk.V4i1.10347.

Sari, F. K., Rakimahwati, R., \& Fitria, Y. (2019). Hubungan Minat Dengan Hasil Belajar Peserta Didik Pada Pelajaran Matematika Kelas VI SDN 25 Jati Tanah Tinggi. Journal Of Elementary Education, 3(2). Https://Doi.Org/Https://Doi.Org/10.31004/Basicedu.V3i2.18.

Satyawan, I. M. (2015). Survei Sarana Dan Prasarana Dalam Pembelajaran Penjasorkes Di SMA/SMK/MA Kabupaten Buleleng Tahun Pelajaran 2014/2015, 2(1), 28-38. Https://Doi.Org/10.23887/Penjakora.V2i1.11308.

Sugiyono. (2016). Metode Penelitian Kuantitatif, Kualitatif, Dan R \& D. Bandung: Alfabeta.

Sukardi. (2008). Metodelogi Penelitian Pendidikan Kompetensi Dan Praktiknya. Jakarta: Bumi Aksara.

Suprianto, D. (2020). Minat Peserta Didik Dalam Mengikuti Pembelajaran PJOK Pada Masa Pandemi Covid19 Di Kelas XI SMK Negeri 2 Negara. Indonesian Journal of Sport \& Tourism, 2(1), 8-14. Https://Doi.Org/10.23887/Ijst.V1i1.34831.

Sutapa. (2020). Efektifitas Pembelajaran Jarak Jauh Dengan Daring Selama Pandemi CoVID-19 Mata Pelajaran Pendidikan Jasmani Olahraga Dan Kesehatan (PJOK). Pediatric Critical Care Medicine, 1(1), 19-29.

Verawati, R., Tegeh, I. M., \& Antara, P. A. (2020). Hubungan Antara Minat Baca Dan Motivasi Berprestasi Dengan Hasil Belajar Ilmu Pengetahuan Sosial Siswa. Mimbar PGSD Undiksha, 8(3), 351-363. Https://Doi.Org/10.23887/Jjpgsd.V8i3.25518.

Wardika, I. N. (2019). Penerapan Permainan Tradisional Untuk Mengatasi Kejenuhan Belajar PJOK. Journal Of Education Action Research, 3(3), 231-240. Https://Doi.Org/Https://Doi.Org/10.23887/Jear.V3i3.17377.

Widiartini, N. K. (2017). Uji Validitas Instrumen Pengukuran. Seminar Nasional Riset Inovatif 2017, 1(1), 530-535.

Yunitasari, R., \& Hanifah, U. (2020). Pengaruh Pembelajaran Daring Terhadap Minat Belajar Siswa Pada Masa COVID 19. Edukatif: Jurnal Ilmu Pendidikan, 2(3), 232-243. Https://Doi.Org/10.31004/Edukatif.V2i3.142. 